fellowship of the Royal Society and four of them have received Nobel prizes. This side of the Commissioners' work-and it is by no means the only side-is perhaps the most notable of their achievements since under the inspiring lead of the Prince Consort they set themselves their first task of developing as a great educational centre the property purchased at South Kensington with the proceeds of the Great Exhibition.

\section{The Institute of Metals}

Two important announcements were made by the president of the Institute of Metals, Mr. W. R. Barclay, at the annual general meeting on Wednesday, March 10. The first dealt with co-operation with two sister institutes. As a first step in a scheme of co-operation with the Iron and Steel Institute, members of each Institute can become members of the other without formality other than written application. Combined annual subscriptions and entrance fees have also been arranged. The present scheme of co-operation follows one recently completed by the two Institutes with the American Institute of Mining and Metallurgical Engineers whereby members, associates and student members of the British Institutes may, if under the age of thirty-three years, become junior foreign affiliates of the American Institute of Mining and Metallurgical Engineers on specially favourable terms, the arrange$m \in n t$ being reciprocal in the case of members of the American Society. The president also announced that the Council had decided to issue an appeal for the creation of an Endowment Fund, to be invested for the support and extension of the work of the Institute. For the last few years the margin between income and expenditure in the annual accounts had been very narrow, and had afforded little or no opportunity to strengthen the Institute's financial reserves. Economies had been effected wherever possible, but these could not be extended without seriously curtailing the service the Institute renders to its members and to the industry in general. In the judgment of the Council the time had arrived when, on the basis of the record and achievements of the Institute, an appeal could and should be made to the non-ferrous metals industry for a substantial capital sum which it was hoped would appreciably lessen the anxiety constantly felt by the Council and its committees as to the financial future. He was glad to be able to announce that promises or actual contributions amounting to about $£ 14,000$ had already been received.

\section{Prehistoric Cultures and Chronology in North Africa}

THE most recent contribution of M. R. Vaufrey to discussion of a group of chronological and cultural problems in the archæology of North Africa, of which an account appears in another column of this issue of NATURE (see p. 432), is of more than local interest in its bearing on questions of wide import in the study of prehistoric civilizations. M. Vaufrey, the distinguished anthropologist who occupies a chair in the Institut de Paléontologie humaine in Paris, has explored extensively over a number of years among the prehistoric sites of North Africa, and his studies in the classification of the cultures and in the prehistory of that region are accorded the authority due no less to his meticulous precision as an investigator in the field than to his ability in the analysis of archæological evidence recorded by others. In his latest contributions to a subject upon which no one is thus better qualified than himself to speak, M. Vaufrey has two main objectives.

IN the first place, M. Vaufrey's aim is to determine with such precision as the case warrants the cultural association and dating thereby of the 'fossil' man of Mechta el-Arbi, a problem of no little moment in the history of the development of early types of 'modern' man in the Mediterranean area; and secondly, to determine the age which should be assigned to the characteristic art form of prehistoric North Africa, the rock engravings of varied forms of animal life in naturalistic style, a question long a matter of controversy among archæologists, of which the suggested solutions have ranged from the palæolithic to the Iron age or later. By his conclusions that this type of early man belongs to the Mesolithic age and even later, the early Neolithic, while the cultures with which he is associated, by correlation with the early civilizations of the Nile valley, can be fixed in terms of years at a period extending from the beginning of the fourth millennium, down to the middle or even the end of the second millennium B.C., M. Vaufrey arrives at a result which will be of the first importance when brought into relation with the study of mesolithic and early neolithic cultures throughout the whole range of cultural distributions in the ancient world.

\section{Prehistoric Caves in Kent}

A RECEnT subsidence of earth at St. Mary Cray, Kent, has revealed the existence of a subterranean cavity, which, it is thought, may prove to be the entrance to a considerable system of caves, similar to that at Chislehurst, two and a half miles away to the south, where thirty miles of galleries have been explored since the caves were rediscovered in 1902 . Marks of deer-horn picks, still clearly visible, show where prehistoric man cut away the chalk. Although it will not be possible to attempt to explore the caves at St. Mary Cray until the fallen subsoil has been removed, entrance to two chambers, it is stated in The Times of March 4, has been made by Mr. GibsonCowan and Mr. Geoffrey Edwards, who found them to be about five feet high by thirty feet long. Probing with a pole ten feet long at the end of the farther chamber failed to encounter obstructing chalk, and it may be concluded, therefore, that they extend in this direction, while the existence of an earlier subsidence a quarter of a mile away, suggests that there may be a system of connected caves of considerable extent. The Chislehurst caves have produced few archæological relics; but as an Elizabethan villa has been shown to have had direct access to the caves by means of a stair, and the caves were used as refuges, 